\title{
The evaluation of health-related behaviours between the physically active and non-active women
}

\begin{abstract}
Introduction. In the face of the more and more general threat with civilization diseases the promotion of healthy lifestyle should be one of main activities of educational and medical institutions.

Aim. The aim of the work was comparison of chosen elements of healthy lifestyle between the young physically active women and non-sports ones.

Material and methods. The survey was carried out on 156 women aged 18-35 years, divided into two groups. Persons physically active were classified into Group $1(\mathrm{n}=72)$, whereas into Group 2 - non-active ones ( $\mathrm{n}=84)$. The investigative tool was the Inventory of Health-Related Behaviours by Juczyński (where health-related behaviours were rated in four categories: proper nutrition habits, prophylaxis behaviours, and positive attitude and health practices). Differences between the data were qualified with the $t$-student test for independent groups; level $\mathrm{p} \leq 0.05$ was accepted as of minimum significance.

Results. The results show that physically active persons pay greater attention to healthy lifestyle than non-sports people. The general indicator of health-related behaviours was noticeably higher in Group $1(\mathrm{p}=0.007)$. Greatest differences $(\mathrm{p}=0.008)$ were noted within the range of nutritional habits, and the least significant ones - in positive attitude $(p=0.546)$.

Conclusion. The positive influence of the physical activity on other aspects of the healthy lifestyle has been proven. It seems legitimate to promote physical activity among women of every age.
\end{abstract}

Keywords: physical activity, health behaviours, lifestyle, women.

DOI: $10.2478 /$ pjph-2014-0002

\section{INTRODUCTION}

The problem of civilization diseases concerns increasingly more persons. A lifestyle plays a special role in prophylaxis, especially of these diseases which are developed as a result of harmful habits. The greatest and most dangerous group of diseases are the ones of circulatory system. They are the major cause of premature deaths in Europe [1-5]. In Poland in 2006 they determined the reason of $46 \%$ of all deaths [4]. At sources of circulatory system diseases lie most simple health-related behaviours - such as quality and quantity of consumed meals, taking of stimulants (cigarettes, liquor), or the activity and physical fitness levels [4]. Enlarged body mass can be the first symptom. It is estimated that in fully developed countries percentage of overweight and obese persons exceeds $50 \%$ of population [6]. Therefore physical activity is becoming more and more often promoted as one of educational actions of governments, autonomies and non-governmental organizations $[5,7]$.

Physically active persons are often conscious of the role of lifestyle in the maintenance of health, which is why they more seldom smoke cigarettes eat healthier and more often do preventive check-ups. What is more, physical efficiency is one of measures of health state of a man. It conditions the ability of taking up some physical effort both in professional work as well as in everyday life. The maintenance of the optimum-level of efficiency allows the organism some heavy and/or prolonged manual work, engaging large muscular groups, without the quickly increasing feeling of the fatigue and considerable disturbances of homeostasis. Systemic results of the inertness fundamentally contribute to decreasing of physical and psychical fitness of the organism, which is connected with worsening of the optimum functioning in different situations [8].

\section{AIM}

The aim of the research was the estimation of chosen health-related behaviours of young women, taking into account their physical activity.

\footnotetext{
${ }^{1}$ Department of Rehabilitation, Physiotherapy Division, Medical University of Warsaw, Poland

${ }^{2}$ Department of Theory of Sport, Józef Piłsudski University of Physical Education in Warsaw, Poland

${ }^{3}$ Students Scientific Association of Physiotherapy, Medical University of Warsaw, Poland
} 


\section{MATERIAL AND METHODS}

Women (18-35 years old) from Warsaw, Poland $(n=156)$ partook in the research. All participants were healthy with normal body weight (BMI 18.5-24.99). Examined persons were divided into two groups: physically active - Group $1(\mathrm{n}=72)$ and non-active - Group $2(\mathrm{n}=84)$. Women from Group 1 were involved with the sports classes (minimum 2 per week) in fitness clubs. The detailed biometrical characterization of the examined persons, with the regard of the division to groups, was placed in the Table 1.

TABLE 1. Characteristics of research groups.

\begin{tabular}{lcccc}
\hline \hline & $\begin{array}{c}\text { number of } \\
\text { people (n) }\end{array}$ & $\begin{array}{c}\text { age } \\
\text { (years) }\end{array}$ & $\begin{array}{c}\text { body height } \\
(\mathrm{cm})\end{array}$ & $\begin{array}{c}\text { body mass } \\
(\mathrm{kg})\end{array}$ \\
\hline Group 1 & \multirow{2}{*}{72} & 24.89 & 166.56 & 59.33 \\
(active) & & \pm 4.7 & \pm 5.3 & \pm 6.6 \\
\hline Group 2 & \multirow{2}{*}{84} & 24.79 & 167.38 & 59.67 \\
(non-active) & & \pm 5.3 & \pm 6.4 & \pm 6.4 \\
\hline
\end{tabular}

The investigative tool was the Inventory of HealthRelated Behaviours by Juczyński (where health-related behaviours were rated in four categories: eating habits, prophylaxis behaviours, and positive attitude and health practices. The questions in the inventory refer to four categories of health-related behaviours (HRB): proper nutritional habits $(\mathrm{NH})$ that is the kind of consumed food, the frequency of meals, prophylaxis behaviours (PB) that is abiding by health recommendations, learning about health and illness, positive attitude (PA) that is avoidance of strong excitements, tensions, stresses, and health practices (HP) that is everyday activities containing physical activity, sleep and recreation [9]. Additionally the author's questionnaire containing the biometrical information was carried out.

Standard statistical tools were used in the compilation of the material- the arithmetical mean together with the standard deviation. Dependences between the features were qualified by means of the Pearson's correlation. Differences among each data were counted with the use of t-student test for independent groups. The level $\mathrm{p} \leq 0.05$ was fixed as of minimum significance one.

\section{RESULTS}

On the ground of gathered data, by means of the Inventory of Health-Related Behaviours, it was determined that the level of declared health-related behaviours and connected practices in studied groups was on the average level (the value of the HRB indicator for Group 1 was 82.42, for Group 2: 77.53). Physically active women were characterized with significantly higher level of health-related behaviours $(p=0.007)$. Significantly higher results of Group 1 were noted in three out of four components of the IHRB - proper nutrition habits, prophylaxis behaviours and health practices (Table 2).

There were observed no characteristic differences between the level of health-related behaviours of younger women (up to 24 years old) and older ones (above 25 years old), in none of the categories. In the subgroup of persons below 24 year of life, physically active women characterized themselves with the higher HRB level. Similar dependencies were not observed among older persons - above 25 years old (Table 3).

Women practicing sport in the past (physically active and non-sports ones) obtained significantly higher result in the category of positive attitude. Among persons with the sports-past, women remaining physically active brought to light higher HRB level in categories of nutritional habits and prophylaxis behaviours (Table 3 ).

TABLE 2. Level of health-related behaviors of examined women physically active (Group 1) and non-active (Group 2).

\begin{tabular}{lccccc}
\hline \hline & NH & PB & PA & HP & HRB \\
\hline Group 1 $(\mathrm{n}=72)$ & $\begin{array}{c}3.57 \\
\pm 0.71\end{array}$ & $\begin{array}{c}3.42 \\
\pm 0.72\end{array}$ & $\begin{array}{c}3.46 \\
\pm 0.58\end{array}$ & $\begin{array}{c}3.28 \\
\pm 0.54\end{array}$ & $\begin{array}{c}82.42 \\
\pm 11.19\end{array}$ \\
\hline \multirow{2}{*}{ Group 2 (n=84) } & $\begin{array}{c}3.27 \\
\pm 0.71\end{array}$ & $\begin{array}{c}3.16 \\
\pm 0.7\end{array}$ & $\begin{array}{c}3.41 \\
\pm 0.53\end{array}$ & $\begin{array}{c}3.08 \\
\pm 0.59\end{array}$ & $\begin{array}{c}77.53 \\
\pm 10.85\end{array}$ \\
\hline $\mathrm{p}$ & 0.008 & 0.025 & 0.546 & 0.031 & 0.007 \\
\hline
\end{tabular}

TABLE 3. Level of health-related behaviors of examined women (divided into subgroups).

\begin{tabular}{|c|c|c|c|c|c|c|c|}
\hline & & & $\mathrm{NH}$ & PB & PA & HP & HRB \\
\hline \multirow{9}{*}{ 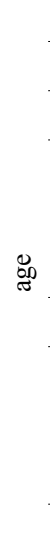 } & \multicolumn{2}{|c|}{$<25(\mathrm{n}=91)$} & 3.34 & 3.21 & 3.45 & 3.14 & 78.85 \\
\hline & \multicolumn{2}{|c|}{$\geq 25(\mathrm{n}=65)$} & 3.50 & 3.38 & 3.42 & 3.22 & 81.09 \\
\hline & \multicolumn{2}{|c|}{$\mathrm{p}$} & 0.163 & 0.143 & 0.729 & 0.401 & 0.206 \\
\hline & \multirow{2}{*}{$<25$} & $\begin{array}{c}\text { Group } 1 \\
(\mathrm{n}=44)\end{array}$ & 3.58 & 3.34 & 3.46 & 3.23 & 81.64 \\
\hline & & $\begin{array}{c}\text { Group } 2 \\
(n=47)\end{array}$ & 3.12 & 3.08 & 3.44 & 3.06 & 76.24 \\
\hline & \multicolumn{2}{|c|}{$\mathrm{p}$} & 0.005 & 0.098 & 0.883 & 0.198 & 0.033 \\
\hline & \multirow{2}{*}{$\geq 25$} & $\begin{array}{c}\text { Group } 1 \\
(n=28)\end{array}$ & 3.56 & 3.54 & 3.48 & 3.36 & 83.64 \\
\hline & & $\begin{array}{c}\text { Group } 2 \\
(\mathrm{n}=37)\end{array}$ & 3.45 & 3.26 & 3.37 & 3.11 & 79.16 \\
\hline & & $\mathrm{p}$ & 0.480 & 0.092 & 0.432 & 0.050 & 0.068 \\
\hline \multirow{9}{*}{ 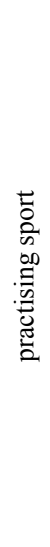 } & former atl & letes $(n=62)$ & 3.44 & 3.31 & 3.56 & 3.17 & 80.85 \\
\hline & non-athl & tes $(n=94)$ & 3.39 & 3.26 & 3.36 & 3.18 & 79.08 \\
\hline & & $\mathrm{p}$ & 0.696 & 0.665 & 0.025 & 0,939 & 0.356 \\
\hline & \multirow{2}{*}{$\begin{array}{l}\text { former } \\
\text { athletes }\end{array}$} & $\begin{array}{c}\text { Group } 1 \\
(n=22)\end{array}$ & 3.81 & 3.60 & 3.62 & 3.32 & 86.07 \\
\hline & & $\begin{array}{c}\text { Group } 2 \\
(n=40)\end{array}$ & 3.23 & 3.15 & 3.52 & 3.09 & 77.98 \\
\hline & & $\mathrm{p}$ & 0.010 & 0.043 & 0.474 & 0.142 & 0.014 \\
\hline & \multirow{2}{*}{$\begin{array}{c}\text { non-ath- } \\
\text { letes }\end{array}$} & $\begin{array}{l}\text { Group } 1 \\
(n=50)\end{array}$ & 3.47 & 3.34 & 3.40 & 3.27 & 80.81 \\
\hline & & $\begin{array}{c}\text { Group } 2 \\
(\mathrm{n}=44)\end{array}$ & 3.30 & 3.17 & 3.31 & 3.08 & 77.12 \\
\hline & \multicolumn{2}{|c|}{$\mathrm{p}$} & 0.208 & 0.216 & 0.456 & 0.104 & 0.086 \\
\hline
\end{tabular}

\section{DISCUSSION}

Lifestyle is the most important factor conditioning the maintenance of health and psychophysical efficiency. One of the main elements of healthy lifestyle is the physical activity. Its deficiency is one of reasons of enlarged morbidity from civilization diseases. The research carried out by Charzewski evidenced the fall of motor activity with age [10]. 
It refers particularly to women. The age has an influence also on the choice of the form of physical activity. Among 25 -year old women only just about $12 \%$ take part in organized sports-recreational classes. With the age this percentage is yet smaller [11].

Quite often, a justification of women for taking up the physical effort is a wish of strengthening the position in the professional life. For women this aspect is almost as important as health-related consideration [12]. The motor activity, taken up by women, is also related to belief about the increase of authority both at work as well as the house [10]. Parnicka, similarly to other authors, among forms of physical activity most preferred in the group of adult females, mentions: walks, cycling and body forming exercises [13]. After-work house chores, shopping and taking care of children are the factors limiting motor activity $[11,13]$. On the other hand, active and physically efficient women are better prepared to motherhood, more seldom have pain complaints during pregnancy, spend less time on sick leaves and better cope with household duties [14-16].

Drabik, similarly to Charzewski, noticed that motor activity undertaken by men above 35 year of life was slight and undertaken by less than $10 \%$ population. For most, the physical effort limits itself to a one-kilometre-long walk, which is due to the collection of one's own child from the nursery school or school. Shorter distances are walked to a car standing on the parking space $[10,17]$. Few works show different data, according to which the physical activity of the Polish society is not on so low level as suggested by most of authors [18,19].

Research on different aspects of women's lifestyle is carried out often enough [20-22]. The Inventory of HealthRelated Behaviours was used in research on other social groups (the youth, students). The results obtained by Kozieł, Lewko and Naszydłowska were close to the results of present work. They showed namely the average level of health-related behaviours of respondents [23-25].

Practicing sport (even having practiced it in the past) seems to be an interesting aspect as the element of health education. The diagnosis of health-related behaviours of handicapped sportsmen showed that not only they had better coped with barriers of the everyday life, what is self-evident, but also paid greater attention to the lifestyle - especially within the range of healthy nourishment [26]. Own research proved that even non-sports women which in the past were active competitors were characterized with the higher level of health-related behaviours than active persons who have no sports-past. Similar conclusions were reached by WoitasŚlubowka who compared former sportsmen $(n=312)$ to nonsports persons $(n=417)$ [27]. Physical activity besides the influence on physiological parameters can also bear on the awareness level of exercising people; therefore, its promotion can bring twofold advantages.

\section{CONCLUSIONS}

1. Physical activity had an influence on general health-related behaviours. Active persons were more health-aware especially of proper nutrition habits. This proves intellec- tualisation of the process of health-related training and of the transfer of desirable behaviours into everyday life.

2. In the light of obtained results it seems legitimate to continue the promotion of physical activity in all social groups.

\section{REFERENCES}

1. Anokye NK, Trueman P, Green C, et al. Physical activity and health related quality of life. BMC Public Health. 2012;12:624.

2. Dey M, Gmel G, Mohler-Kuo M. Body mass index and healthrelated quality of life among young Swiss men. BMC Public Health. 2013;13(1):1028. [Epub ahead of print]

3. Ekblom-Bak E, Ekblom B, Vikström M, et al. The importance of nonexercise physical activity for cardiovascular health and longevity. Br J Sports Med. doi: 10.1136/bjsports-2012-092038. [Epub ahead of print]

4. Ślusarska B, Nowicki G. Health behaviours in prophylaxis of cardiovascular diseases among occupationally active population. Probl Hig Epidemiol. 2010;91(1):34-40.

5. Tiszczenko EM, Surmach MJ, Piecewicz-Szczęsna B. Health behaviors as an essential health factor. Zdr Publ. 2009;119(1):86-9.

6. Szymocha M, Bryła M, Maniecka-Bryła I. The obesity epidemic in the 21st century. Zdr Publ. 2009;119(2):207-12.

7. Kirag N, Ocaktan EM. Analysis of health promoting lifestyle behaviors and associated factors among nurses at a university hospital in Turkey. Saudi Med J. 2013;34(10):1062-7.

8. Drabik J. Aktywność fizyczna w edukacji zdrowotnej społeczeństwa. Gdańsk: AWF Gdańsk; 1995.

9. Juczyński Z. Narzędzia pomiaru w promocji i psychologii zdrowia. Warszawa: PTP; 2001.

10. Charzewski J. Aktywność sportowa Polaków. Warszawa: COS; 1997.

11. Napierała M, Nowicki G. Wiek jako czynnik różnicujący wybór formy aktywności. Wych Fizycz Sport. 2002;46(Suppl. 1):160-2.

12. Salita J. Uczestnictwo Polaków w rekreacji ruchowej. Wych Fizycz Sport. 2002;46(Suppl. 1): 174-5.

13. Parnicka U. Czynniki inspirujące aktywność ruchową kobiet. Wych Fizycz Sport. 2002;46(Suppl. 1):162-3.

14. Mogren IM. Previous physical activity decreases the risk of low back pain and pelvic pain during pregnancy. Scandinavian J Public Health. 2005;33:300-6.

15. Rutkowska E, Łepecka-Klusek C. The role of physical activity in preparing women for pregnancy and delivery in Poland. Health Care for Women Int. 2002;23:919-23.

16. Sabino J, Grauner JN. Pregnancy and low back pain. Curr Rev Musculoskel Med. 2008;1:137-41.

17. Drabik J, Drabik P, Resiak M. Aktywność fizyczna populacji gdańskiej w wybranych grupach wiekowych. Wych Fizycz Zdr. 2001;4:11-4.

18. Piątkowska M. Prevalence of physical activity in the Polish society. 10th International Scientific Conference "New ideas in fundamentals of human movement and sport science, current issues and perspective". Belgrad; 2007. p.161-6.

19. Biernat E, Piątkowska M, Gajewski A. Participation in sport, motor leisure activities and physical activity of teachers from two different universities. Wrocław: New Horizons; 2006. p. 25-33.

20. Baheiraei A, Mirghafourvand M, Charandabi S, et al. Health-promoting behaviors and social support in Iranian women of reproductive age: a sequential explanatory mixed methods study. Int J Public Health. doi: 10.1007/s00038-013-0513-y [Epub ahead of print]

21. Kolarczyk E, Szot W, Pastucha E, et al. Physical and mental components of life quality among women aged between 45 and 60 years in Polish national research. Part 10. Collective results. Probl Hig Epidemiol. 2009;90(4):548-52.

22. Walentukiewicz A, Łysak A, Wilk B. Selected health attitudes (physical activity and nutrition) of 18-year-old girls graduating from secondary schools of Tricity. BJHPA. 2011;3(2):112-20.

23. Kozieł D, Naszydłowska E, Trawczyńska M, Czerwiak G. Youth’s healthy behawior as a direction for healthcare education. Zdr Publ. 2003;113(3/4):280-4.

24. Lewko J, Polityńska-Lewko B, Sierakowska M, Krajewska-Kułak E. Zachowania zdrowotne wśród studentów pielęgniarstwa. Ann Univ Mariae Curie-Skłodowska. Lublin; 2005. p. 260-4. 
25. Naszydłowska E, Kozieł D, Trawczyńska M. Ocena zachowań zdrowotnych młodzieży oraz ustalenie kierunków ich modyfikacji. Ann Univ Mariae Curie-Skłodowska, Lublin 2003: 354-359.

26. Boguszewski D, Adamczyk JG, Ochal A, et al. Ocena wybranych zachowań zdrowotnych niepełnosprawnych sportowców. Post Reh. 2011;25(4):57-62.

27. Woitas-Ślubowska D. Influence of patricipation in leisure time physical activity on tobacco and alcohol consumption among former athletes and non-athletes. J Hum Kin. 2009;21:119-26.

\section{Corresponding author}

Dariusz Boguszewski

Medical University of Warsaw, Rehabilitation Department,

81 Żwirki i Wigury Str., 02-091 Warsaw, Poland

Phone/fax: +48 22 572-09-20,

E-mail: dboguszewski@wum.edu.pl 